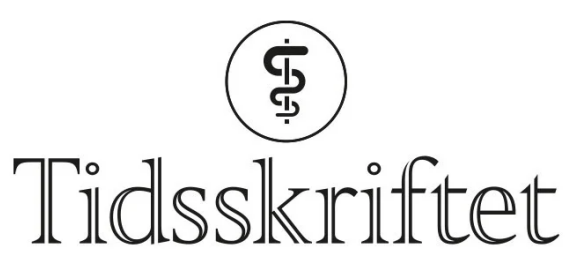

DEN NORSKE LEGEFORENING

\title{
Spredt om ultralyd
}

\author{
ANMELDELSER
}

ANDREAS W. ESPINOZA

Anestesi og intensivklinikken

Oslo universitetssykehus, Rikshospitalet



Bolliger, CT

Herth, FJF

Mayo, PH

Clinical chest ultrasound

From the ICU to the bronchoscopy suite. 221 s, tab ill. Basel: Karger, 2009. Pris CHF 188.

ISBN 978-3-8055-8642-9

Boken er ment for ultralydinteresserte lungeleger og intensivleger, og tar sikte på å gi en oversikt over ultralydanvendelse for bildediagnostikk og -veiledning i thoraxregionen. Den er inndelt i fem seksjoner, med temaer fra basal ultralydfysikk via transtorakal diagnostikk til applikasjoner på intensivavdelingen og innen endoskopisk ultralyd. Kapitlene er skrevet som oversiktsartikler, med illustrasjoner og oppdaterte referanselister. Teksten ledsages også av videoillustrasjoner som er tilgjengelige på et Internett-register (www.karger.com/PRRo37_suppl). 
Boken gir en god innføring og oversikt innen forskjellige emner; både mer konvensjonelle applikasjoner som transtorakal pleura- og lungevurdering, men også nyere teknikker som navigasjonsbronkoskopi og «optical coherence tomography». Enkelte kapitler omhandler større temaer på liten plass, og fremstår derfor vel summariske (f.eks. Critical care echocardiography). Endobronkial ultralyd brukes i økende grad for biopsi av lymfeknuter og stadievurdering i kreftdiagnostikk. Dette temaet er viet god plass, dog med mye oppmerksomhet på instrumentutvikling (fire kapitler). Det er noen gjentakelser, blant annet blir ultralydfysikk berørt i flere av kapitlene. Det er unødvendig så lenge det også er viet et eget kapittel.

Videoillustrasjonene er dessverre ikke godt nok utnyttet. Når man må skifte medium for å se illustrasjonene, burde de kunne stå på egen hånd. Manglende «figurtekst» eller kommentar gjør at de gir utilstrekkelig informasjon, og feilindeksering av illustrasjonene forekommer enkelte steder (f.eks. «Use of ultrasound for central venous access»).Videoillustrasjonene til kapitlene om endoskopisk ultralyd er mer informative, flere av dem med animasjoner som tar seeren «inn i» bronkialtreet og viser hvor endoskopiog ultralydbilder er tatt opp.

Mange av kapitlene gir fin oversikt innen emnet, men boken fremstår som tematisk spredt, iallefall etter norske forhold. Dette skyldes nok delvis at f.eks. i USA er lunge- og intensivmedisin nærere koblet enn det som er vanlig i Norge. Her hjemme er dette en bok for spesielt interesserte lungemedisinere eller intensivmedisinere.

Publisert: 14. januar 2010. Tidsskr Nor Legeforen. DOI: 10.4045/tidsskr.09.1159

(C) Tidsskrift for Den norske legeforening 2023. Lastet ned fra tidsskriftet.no 26. april 2023. 